\title{
Phenotypic and molecular characterizations of multidrug-resistant diarrheagenic E. coli of calf origin
}

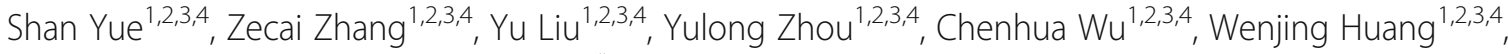
Nannan Chen ${ }^{1,2,3,4}$ and Zhanbo Zhu ${ }^{1,2,3,4^{*}}$ (D)

\begin{abstract}
Escherichia coli has become one of the most important causes of calf diarrhea. The aim of this study is to determine the patterns of antimicrobial resistance of $E$. coli isolates from six cattle farms and to identify prominent resistance genes and virulence genes among the strains isolated from the diarrhea of calves. Antimicrobial susceptibility tests were performed using the disk diffusion method, and PCR was used to detect resistance and virulence genes. The prevalence of multidrug resistant (MDR) E. coli was $77.8 \%$ in dairy cattle and $63.6 \%$ in beef cattle. There were high resistance rates to penicillin $(100 \%, 100 \%)$ and ampicillin $(96.3 \%, 86.4 \%)$ in E. coli from dairy cattle and beef cattle. Interestingly, resistance rate to antimicrobials and distribution of resistance genes in $E$. coli isolated from dairy cattle were higher than those in beef cattle. Further analysis showed that the most prevalent resistance genes were bla TEM and aadA1 in dairy cattle and beef cattle, respectively. Moreover, seven diarrheagenic virulence genes (irp2, fyuA, Stx1, eaeA, F41, K99 and STa) were present in the isolates from dairy cattle, with a prevalence ranging from $3.7 \%$ to $22.22 \%$. Six diarrheagenic virulence genes (irp2, fyuA, Stx1, eaeA, hylA and F41) were identified in the isolates from beef cattle, with a prevalence ranging from $2.27 \%$ to $63.64 \%$. Our results provide important evidence for better exploring their interaction mechanism. Further studies are also needed to understand the origin and transmission route of $E$. coli in cattle to reduce its prevalence.
\end{abstract}

Keywords: Dairy calves, Beef calves, E. coli, Multidrug resistant, Virulence gene

\section{Introduction}

Diarrheagenic E. coli (DEC) is a significant cause of gastroenteritis and a major health problem in animals and humans. E. coli infection in calves usually causes a variety of clinical signs, including diarrhea, respiratory infections, and sepsis, and then death due to dehydration and exhaustion because of the difficulties in treatment. Previous studies have shown that diarrhea is the most

\footnotetext{
* Correspondence: zhanbozhu@byau.edu.cn

'College of Animal Science and Veterinary Medicine, Heilongjiang Bayi Agricultural University, Daqing 163319, China

${ }^{2}$ Heilongjiang Provincial Technology Innovation Center for Bovine Disease Control and Prevention, Daqing 163319, China

Full list of author information is available at the end of the article
}

common problem in young calves, causing more than $52 \%$ of deaths in unweaned calves (Diarra et al. 2009). In cattle farms, antimicrobials are the most important therapy for bacterial infection. In dairy cattle farms worldwide, periodic treatment of mastitis after bacterial infection is very common, which not only easily leads to bacterial resistance but also raises concerns about the emergence of multidrug resistant (MDR) bacteria (Yang et al. 2021). The use of antimicrobials to treat infections in beef cattle can increase prevalence of antimicrobial resistance (AMR) in enteric pathogens (Cazer et al. 2017). In addition, antimicrobials are frequently used as growth promoters and preventive agents, which further increases the risk of $E$. coli resistance (Sivaraman et al.

(C) The Author(s). 2021 Open Access This article is licensed under a Creative Commons Attribution 4.0 International License, which permits use, sharing, adaptation, distribution and reproduction in any medium or format, as long as you give appropriate credit to the original author(s) and the source, provide a link to the Creative Commons licence, and indicate if changes were made. The images or other third party material in this article are included in the article's Creative Commons licence, unless indicated otherwise in a credit line to the material. If material is not included in the article's Creative Commons licence and your intended use is not permitted by statutory regulation or exceeds the permitted use, you will need to obtain permission directly from the copyright holder. To view a copy of this licence, visit http://creativecommons.org/licenses/by/4.0/ The Creative Commons Public Domain Dedication waiver (http://creativecommons.org/publicdomain/zero/1.0/) applies to the data made available in this article, unless otherwise stated in a credit line to the data. 
2020). AMR in bacteria of animal origin is considered a major challenge to veterinary medicine and public health (Anes et al. 2020), which not only seriously affects the healthy development of cattle breeding industry but also poses a serious threat to food safety. E. coli has also been used as a sentinel organism for monitoring AMR (de Moyaert et al. 2014). Hence, monitoring AMR in cattle is important to human and animal health.

Some pathogenic $E$. coli strains use different virulence factors to colonize the hosts' small intestine, avoiding immune response and stimulating the deleterious inflammatory response to produce diarrhea (Croxen and Brett Finlay 2010). Virulence genes that play significant roles in E. coli pathogenicity are associated with diarrhea in animals and humans have been described (Fröhlicher et al. 2008; Huehn et al. 2010). Among the many virulence genes identified in $E$. coli isolates from cattle, Shiga toxins (Stx 1 and Stx2), Yersinia high pathogenicity island (irp2 and $f y u A)$ and intimin (eaeA) were the most significant genes with great public health concerns (Momtaz et al. 2012; Olsson et al. 2003; Momtaz et al. 2013a, b). Cattle are a major reservoir of $E$. coli, particularly Shiga toxin-producing E. coli (STEC) O157:H7. In addition, E. coli has many serotypes, among which $E$. coli O157 can cause hemorrhagic colitis and hemolytic uremic syndrome (Iweriebor et al. 2015). Heat-labile enterotoxins $(L T)$ and heat-stable enterotoxins (STa or $S T b)$ are the two most important virulence factors responsible for severe diarrhea in cattle (Nguyen et al. 2011; Kumar et al. 2013). The most important adhesins involved in E. coli host colonization are fimbriae. Wellcharacterized fimbriae of $E$. coli isolated from animals include F4 (K88), F5 (K99), F6 (987P), F41 and F18, are associated with $E$. coli pathotypes (Maciel et al. 2019). Previous studies have also shown that the ability of $E$. coli to acquire many different virulence factors may lead to the emergence of invasive strains, which pose a threat to human and animal health (Mellmann et al. 2011). Therefore, the aim of this study is to characterize AMR and identify different resistance genes and virulence genes in E. coli strains isolated from dairy cattle and beef cattle to provide a reference for clinical practice.

\section{Results}

\section{Prevalence of AMR in E. coli isolated from dairy and beef} cattle

A total of $71 \mathrm{E}$. coli isolates were obtained, including 27 isolates from dairy cattle and 44 isolates from beef cattle diarrheal fecal samples. Subsequently, susceptibility to 15 different antimicrobials was determined for these 71 E. coli isolates. All 27 E. coli isolates from dairy cattle were resistant to penicillin, followed by ampicillin (96.3\%), amoxicillin and sulfamethoxydiazine (81.5\%), tetracycline and compound sulfamethoxazole (77.8\%), with the lowest resistance rate being observed for florfenicol (33.3\%) (Fig. 1). Meanwhile, all isolates were sensitive to polymyxin B (100\%). Consistent with the results of dairy cattle, the most sensitive antimicrobial was also polymyxin B in the 44 isolates from beef cattle (Fig. 2). The highest resistance rate was also observed for penicillin $(100 \%)$, which may be related to the widespread use of penicillin for the treatment of $E$. coli disease. Further analysis showed that the resistance rate of $E$. coli to antimicrobials (except for florfenicol and polymyxin B) in dairy cattle was higher than that in beef cattle.

\section{Prevalence of multidrug resistant (MDR) E. coli}

Multidrug resistance was defined as resistance by an isolate to at least three antimicrobials of the panel belonging to different classes. Resistance of $E$. coli to seven different types of antimicrobials were analyzed. The results showed that multidrug resistance rates were $77.8 \%$ $(21 / 27)$ in dairy cattle and $63.6 \%(28 / 44)$ in beef cattle. Most isolates from dairy cattle and beef cattle were resistant to five or six different types of antimicrobials. The prevalence of resistance to five different types of antimicrobials was $37 \%(10 / 27)$ in dairy cattle and $18.2 \%$ $(8 / 44)$ in beef cattle. Compared with the isolates from dairy cattle, isolates from beef cattle had a higher prevalence of resistance to six different types of antimicrobials [dairy cattle $29.6 \%(8 / 27)$ vs. beef cattle $31.8 \%(14 / 44)$ ] (Table 1). One isolate from beef cattle was resistant to all antimicrobials.

\section{Prevalence of resistance genes in $E$. coli}

Prevalence of 12 different resistance genes was analyzed in E. coli isolates from dairy cattle and beef cattle origins. The results showed that seven different resistance genes were detected in over 50\% isolates from dairy cattle (Table 2). Resistance genes that had the highest positive rate were bla $a_{\text {TEM }}(100 \%)$, followed by floR, tet (A), , aac (3')-IIa and sul2. Resistance gene with the lowest positive rate was $a a d B(0 \%)$. However, detection rate of seven drug resistance genes in 44 isolates from beef cattle was over $56 \%$, with $100 \%$ positive rate of aadA1, followed by bla $a_{\mathrm{TEM}}$, tet (A), and tet (B) (Table 2). Overall, the positive rates for $b l a_{\mathrm{TEM}}$, aadA1, tet (A), tet (B), floR and sul2 were relatively high in the E. coli isolates of both dairy and beef cattle. Consistent with the AMR results, detection rate of resistance genes in dairy cattle was higher than that in beef cattle.

\section{Correlation between the resistance phenotype and resistance genes}

Consistency analysis of resistance phenotypes and resistance genes to 11 antibiotics showed that $\beta$-lactam (penicillin) resistance phenotype had the highest consistency with $\beta$-lactam resistance genes (beef cattle $K=1$ ), 


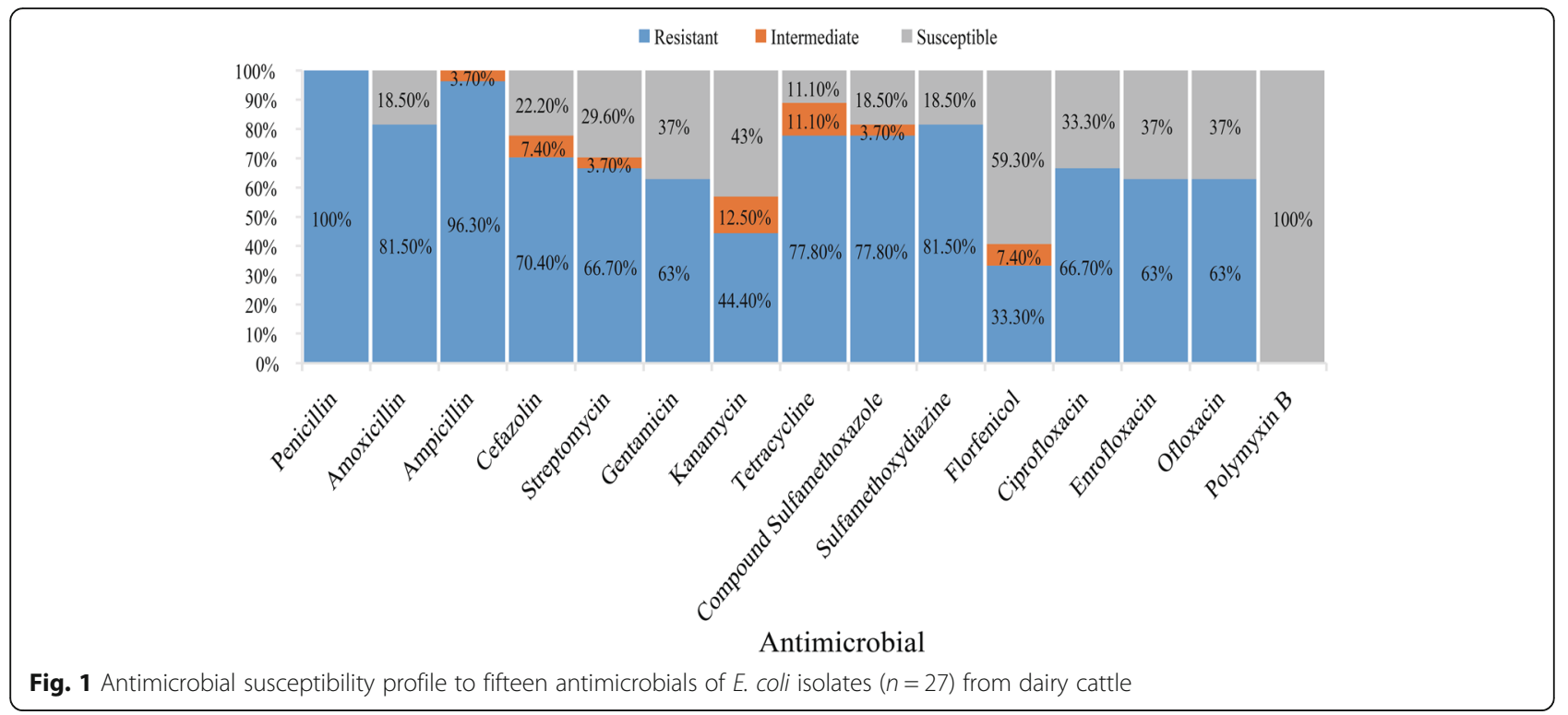

followed by compound sulfamethoxazole (beef cattle $\mathrm{K}=0.59$ ), gentamicin (beef cattle $\mathrm{K}=0.56$ ) and florfenico (beef cattle $\mathrm{K}=0.41$ ). In dairy and beef cattle, tetracycline resistance phenotype had the lowest consistency $(\mathrm{K}=-0.55, \mathrm{~K}=-0.77)$ with tetracycline resistance gene tet $(\mathrm{C})$. Some isolates presenting drug resistance carried resistance genes, whereas some isolates carried resistance genes without manifesting a resistance phenotype (Table 3).

\section{Prevalence of virulence genes in $E$. coli}

A total of 14 virulence genes were present in E. coli isolates from dairy cattle and beef cattle. Seven diarrheagenesis-associated virulence genes (irp2, fyuA, Stx1, eaeA, F41, K99 and STa) were present in isolates from dairy cattle, with a prevalence ranging from $3.7 \%$ to $22.22 \%$. In the isolates from beef cattle, six diarrheagenesis-associated virulence genes (irp2, fyuA, Stx1, eaeA, hylA and F41) were identified, with a prevalence ranging from $2.27 \%$ to $63.64 \%$. In addition, 5 $(18.52 \%)$ isolates from dairy cattle and $19(43.18 \%)$ isolates from beef cattle carried both irp 2 and fyuA. One (3.7\%) isolate from dairy cattle carried eaeA/Stx1/F41 and F41/K99/STa combination, but such a combination was not detected in isolates from beef cattle. In contrast, $8(18.18 \%)$ isolates from beef cattle carried irp2/fyuA/ Stx 1 combination, which were not detected in isolates from dairy cattle. hylA/eaeA/Stx1, irp2/fyuA/F41 and irp2/F41 combinations were detected in 1 (2.27\%), 2 (4.54\%) and $5(11.36 \%)$ isolates from beef cattle, respectively. These combinations were not observed in isolates from dairy cattle (Table 4).

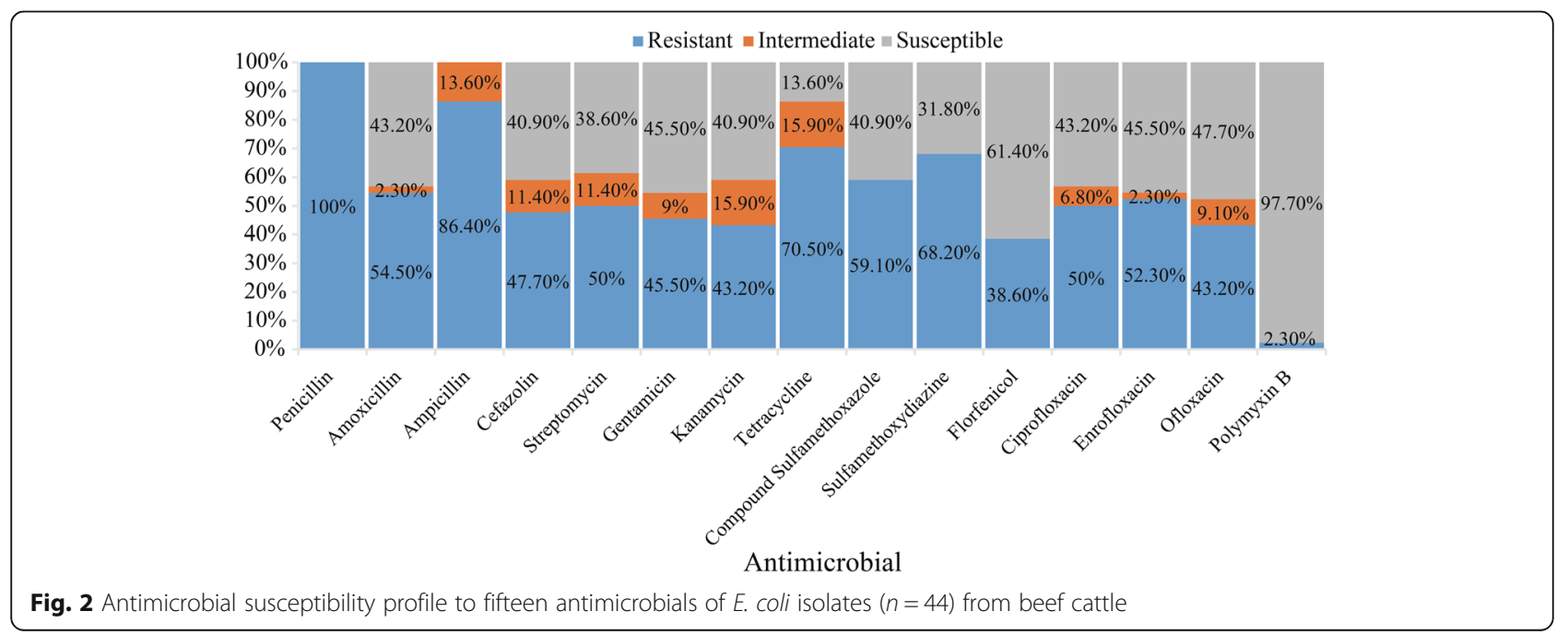


Table 1 Various antimicrobial resistance patterns in 71 E. coli isolates from dairy cattle $(n=27)$ and beef cattle $(n=44)$

\begin{tabular}{|c|c|c|c|c|c|}
\hline \multirow{2}{*}{$\begin{array}{l}\text { Phenotypic } \\
\text { resistance }\end{array}$} & \multirow[t]{2}{*}{ Drug resistance spectrum } & \multicolumn{2}{|c|}{ Dairy cattle (27) } & \multicolumn{2}{|c|}{ Beef cattle (44) } \\
\hline & & Isolates & Rate & Isolates & Rate \\
\hline \multirow[t]{3}{*}{1} & PEN & 0 & $0 \%$ & 3 & $6.81 \%$ \\
\hline & PEN-AMP & 2 & $7.41 \%$ & 7 & $15.91 \%$ \\
\hline & $\begin{array}{l}\text { PEN-AMC-AMP } \\
\text { PEN-AMC-AMP-CFZ }\end{array}$ & 1 & $3.7 \%$ & 1 & $2.27 \%$ \\
\hline \multirow[t]{6}{*}{2} & PEN-SULF & 1 & $3.7 \%$ & & \\
\hline & AMP-SULF & & & 1 & $2.27 \%$ \\
\hline & PEN-TET & & & 2 & $4.55 \%$ \\
\hline & PEN-AMP-COM & 1 & $3.7 \%$ & & \\
\hline & PEN-AMP-TET & & & 1 & $2.27 \%$ \\
\hline & PEN-AMC-AMP-COM-SULF & 1 & $3.7 \%$ & & \\
\hline \multirow[t]{4}{*}{3} & PEN-AMP-TET-SULF & & & 2 & $4.55 \%$ \\
\hline & PEN-AMC-AMP-TET-FFC & 1 & $3.7 \%$ & & \\
\hline & PEN-AMP-TET-COM-SULF & & & 1 & $2.27 \%$ \\
\hline & PEN-AMC-AMP-GEN-TET-COM-SULF & 1 & $3.7 \%$ & & \\
\hline \multirow[t]{2}{*}{4} & PEN-AMC-AMP-KAN-TET-COM-SULF & & & 1 & $2.27 \%$ \\
\hline & $\begin{array}{l}\text { PEN-AMC-AMP-CFZ-STR-TET-COM-SULF } \\
\text { PEN-AMC-AMP-CFZ-TET-COM-SULF-CIP-ENR-OFX }\end{array}$ & 1 & $3.7 \%$ & 1 & $2.27 \%$ \\
\hline \multirow[t]{9}{*}{5} & PEN-AMP-STR-TET-COM-SULF-FFC & & & 1 & $2.27 \%$ \\
\hline & PEN-AMP-KAN-GEN-TET-COM-SULF-CIP-OFZ-ENR & 1 & $3.7 \%$ & & \\
\hline & PEN-AMC-AMP-CFZ-STR-TET-COM-SULF-CIP-OFX- ENR & 2 & $7.41 \%$ & & \\
\hline & PEN-AMC-AMP-CFZ-STR-KAN-TET-COM-SULF-CIP-ENR-OFX & 3 & $11.11 \%$ & & \\
\hline & PEN-AMC-AMP-CFZ-STR-GEN-TET-COM-SULF-CIP-ENR-OFX & 2 & $7.41 \%$ & & \\
\hline & PEN-AMC-AMP-CFZ-STR-GEN-KAN-TET-COM- SULF-CIP-ENR & & & 1 & $2.27 \%$ \\
\hline & PEN-AMC-AMP-CFZ-KAN-GEN-TET-COM-SULF-CIP-ENR-OFX & & & 1 & $2.27 \%$ \\
\hline & PEN-AMC-AMP-CFZ-STR-KAN-GEN-TET-COM-SULF-CIP-ENR-OFX & 2 & $7.41 \%$ & 4 & $9.09 \%$ \\
\hline & PEN-AMC-AMP-CFZ-STR-GEN-KAN-COM-SULF-CIP-ENR-OFX-FFC & & & 1 & $2.27 \%$ \\
\hline \multirow[t]{7}{*}{6} & PEN-AMP-STR-TET--COM-SULF-ENR-FFC & & & 1 & $2.27 \%$ \\
\hline & PEN-AMC-AMP-CFZ-STR-TET-COM-SULF-CIP-FFC & 1 & $3.7 \%$ & & \\
\hline & PEN-AMC-AMP-CFZ-STR-TET-COM-SULF-CIP- ENR-FFC & & & 1 & $2.27 \%$ \\
\hline & PEN-AMC-AMP-STR-GEN-TET-COM-SULF-CIP- ENR-OFX-FFC & & & 1 & $2.27 \%$ \\
\hline & PEN-AMC-AMP-CFZ-STR-GEN-TET-COM-SULF-CIP-ENR-OFX-FFC & 1 & $3.7 \%$ & & \\
\hline & PEN-AMC-AMP-CFZ-STR-GEN-KAN-TET-COM- SULF-CIP-ENR-OFX-FFC & 4 & $14.81 \%$ & 11 & $25 \%$ \\
\hline & PEN-AMC-AMP-CFZ-STR-TET-COM-SULF-CIP-OFZ-ENR-FFC & 2 & $7.41 \%$ & & \\
\hline 7 & $\begin{array}{l}\text { PEN-AMC-AMP-CFZ-STR-GEN-KAN-TET-COM-SULF-CIP-ENR-OFX } \\
\text {-FFC-PB }\end{array}$ & 0 & $0 \%$ & 1 & $2.27 \%$ \\
\hline
\end{tabular}

Note: $\beta$-lactams: penicillin (PEN), amoxicillin (AMC), ampicillin (AMP), and cefazolin (CFZ); aminoglycosides: streptomycin (STR), gentamicin (GEN), and kanamycin (KAN); tetracyclines: tetracycline (TET); sulfonamides: compound sulfamethoxydiazine (SULF); fluoroquinolones: ciprofloxacin (CIP), enrofloxacin (ENR), and ofloxacin (OFX); chloramphenicol: florfenico (FFC); and polypeptides: polymyxin B (PB)

\section{Coexistence of virulence and AMR genes in E. coli}

Further study showed that $49 \mathrm{E}$. coli isolates carried at least one virulence gene, including 38 isolates from beef cattle and 11 isolates from dairy cattle. Subsequently, the coexistence of virulence genes and AMR genes in these $49 \mathrm{E}$. coli isolates were analyzed. The results showed that there were at least 4 AMR genes in the isolates containing virulence genes and up to 10 AMR genes (Table 5) in other isolates. Interestingly, all $49 \mathrm{E}$. coli isolates contained bla $a_{\mathrm{TEM}}$ and tet (A) genes. In addition, most of 38 isolates from beef cattle contained bla ${ }_{\mathrm{TEM}}$, tet (A), tet (B) and floR 
Table 2 E. coli resistance gene detection rate in dairy cattle and beef cattle

\begin{tabular}{|c|c|c|c|c|c|}
\hline Classification & Gene name & Dairy cattle carry number & Positive detection rate & Beef cattle carry number & Positive detection rate \\
\hline \multirow[t]{3}{*}{$\beta$-lactams } & $b / a_{\mathrm{TEM}}$ & 27 & $100 \%(27 / 27)$ & 43 & $97.7 \%(43 / 44)$ \\
\hline & $b l a_{\mathrm{SHV}}$ & 5 & $18.5 \%(5 / 27)$ & 4 & $9.1 \%(4 / 44)$ \\
\hline & $b / a_{\mathrm{OXA}}$ & 4 & $14.8 \%(4 / 27)$ & 3 & $6.8 \%(3 / 44)$ \\
\hline \multirow[t]{3}{*}{ Aminoglycosides } & $\operatorname{aadA1}$ & 19 & $70.4 \%(19 / 27)$ & 44 & $100 \%(44 / 44)$ \\
\hline & $a a c\left(3^{\prime}\right)-11 a$ & 26 & $96.3 \%(26 / 27)$ & 25 & $56.8 \%(25 / 44)$ \\
\hline & $a a d B$ & 0 & $0 \%(0 / 27)$ & 4 & $9.1 \%(4 / 44)$ \\
\hline Chloramphenicols & floR & 26 & $96.3 \%(26 / 27)$ & 26 & $59.1 \%(26 / 44)$ \\
\hline \multirow[t]{3}{*}{ Tetracyclines } & tet $(A)$ & 26 & $96.3 \%(26 / 27)$ & 43 & $97.7 \%(43 / 44)$ \\
\hline & tet (B) & 19 & $70.4 \%(19 / 27)$ & 42 & $95.5 \%(42 / 44)$ \\
\hline & tet $(\mathrm{C})$ & 2 & $7.4 \%(2 / 27)$ & 0 & $0 \%(0 / 44)$ \\
\hline \multirow[t]{2}{*}{ Sulfonamides } & sul1 & 11 & $40.7 \%(11 / 27)$ & 21 & $47.7 \%(21 / 44)$ \\
\hline & sul2 & 26 & $96.3 \%(26 / 27)$ & 34 & $77.3 \%(34 / 44)$ \\
\hline
\end{tabular}

Table 3 Analysis of correlation between antibiotic resistance phenotype and genotype

\begin{tabular}{|c|c|c|c|c|c|c|c|c|}
\hline \multirow[t]{3}{*}{$\begin{array}{l}\text { Antibiotic } \\
\text { (resistance gene) }\end{array}$} & \multicolumn{4}{|c|}{$\begin{array}{l}\text { Dairy cattle } E \text {. coli isolates } \\
\qquad(n=27)\end{array}$} & \multicolumn{4}{|c|}{$\begin{array}{l}\text { Beef cattle } E \text {. coli isolates } \\
\qquad(n=44)\end{array}$} \\
\hline & \multirow[t]{2}{*}{ Genotype } & \multicolumn{2}{|c|}{ Phenotype } & \multirow[t]{2}{*}{ Kappa } & \multirow[t]{2}{*}{ Genotype } & \multicolumn{2}{|c|}{ Phenotype } & \multirow[t]{2}{*}{ Kappa } \\
\hline & & $S$ & $\mathbf{R}$ & & & $S$ & $\mathbf{R}$ & \\
\hline Penicillin & $S$ & 0 & 0 & 0 & $S$ & 1 & 0 & 1 \\
\hline$\left(b / a_{\mathrm{TEM}}\right)$ & $\mathrm{R}$ & 0 & 27 & & $\mathrm{R}$ & 0 & 43 & \\
\hline Amoxicillin & S & 0 & 0 & 0 & $S$ & 1 & 0 & 0.06 \\
\hline$\left(b / a_{T E M}\right)$ & $\mathrm{R}$ & 5 & 22 & & $\mathrm{R}$ & 19 & 24 & \\
\hline Ampicillin & S & 1 & 21 & 0.02 & $S$ & 6 & 34 & 0.03 \\
\hline$\left(b / a_{\mathrm{SHV}}\right)$ & $\mathrm{R}$ & 0 & 5 & & $\mathrm{R}$ & 0 & 4 & \\
\hline Cefazolin & S & 8 & 15 & 0.13 & $S$ & 23 & 18 & 0.15 \\
\hline$\left(b / a_{O \times A}\right)$ & $\mathrm{R}$ & 0 & 4 & & $\mathrm{R}$ & 0 & 3 & \\
\hline Streptomycin & S & 4 & 4 & 0.23 & S & 0 & 0 & 0 \\
\hline (aadA1) & $\mathrm{R}$ & 5 & 14 & & $\mathrm{R}$ & 17 & 27 & \\
\hline Gentamicin & S & 1 & 0 & 0.12 & $S$ & 18 & 1 & 0.56 \\
\hline$\left(a a c\left(3^{\prime}\right)-11 a\right)$ & $\mathrm{R}$ & 9 & 17 & & $\mathrm{R}$ & 9 & 16 & \\
\hline Kanamycin & S & 15 & 12 & 0 & $S$ & 24 & 16 & 0.02 \\
\hline$(\operatorname{aadB})$ & $\mathrm{R}$ & 0 & 0 & & $\mathrm{R}$ & 1 & 3 & \\
\hline Tetracycline & S & 1 & 0 & 0.19 & S & 0 & 1 & -0.04 \\
\hline tet $(A)$ & $\mathrm{R}$ & 6 & 20 & & $\mathrm{R}$ & 13 & 30 & \\
\hline Tetracycline & S & 4 & 4 & 0.29 & $S$ & 2 & 0 & 0.19 \\
\hline tet (B) & $\mathrm{R}$ & 4 & 15 & & $\mathrm{R}$ & 12 & 30 & \\
\hline Tetracycline & S & 5 & 20 & -0.55 & $S$ & 0 & 30 & -0.77 \\
\hline tet $(\mathrm{C})$ & $\mathrm{R}$ & 1 & 1 & & $\mathrm{R}$ & 14 & 0 & \\
\hline Compound Sulfamethoxazole & S & 4 & 12 & 0.06 & S & 18 & 5 & 0.59 \\
\hline (sul1) & R & 2 & 9 & & $\mathrm{R}$ & 4 & 17 & \\
\hline Sulfamethoxydiazine & S & 1 & 0 & 0.29 & $S$ & 6 & 4 & 0.26 \\
\hline (sul2) & $\mathrm{R}$ & 4 & 22 & & $\mathrm{R}$ & 10 & 24 & \\
\hline Florfenico & S & 1 & 0 & 0.08 & S & 18 & 0 & 0.41 \\
\hline$(f l o R)$ & $\mathrm{R}$ & 12 & 14 & & $\mathrm{R}$ & 14 & 12 & \\
\hline
\end{tabular}


Table 4 Distribution pattern of virulence genes in isolates from dairy cattle and beef cattle

\begin{tabular}{|c|c|c|c|}
\hline Virulence Gene & $\begin{array}{l}\text { Isolates from dairy cattle } \\
\text { n (\%) Total = } \mathbf{2 7}\end{array}$ & $\begin{array}{l}\text { Isolates from beef cattle } \\
\mathrm{n}(\%) \text { Total = } 44\end{array}$ & $P$ value \\
\hline irp2 & $22.22 \%(6 / 27)$ & $63.64 \%(28 / 44)$ & $P<0.01$ \\
\hline fyuA & $22.22 \%(6 / 27)$ & $61.36 \%(27 / 44)$ & $P<0.05$ \\
\hline Stx 1 & $3.70 \%(1 / 27)$ & $22.73 \%(10 / 44)$ & $P<0.05$ \\
\hline eaeA & $3.70 \%(1 / 27)$ & $2.27 \%(1 / 44)$ & $P<0.05$ \\
\hline hylA & $0 \%(0 / 27)$ & $2.27 \%(1 / 44)$ & - \\
\hline F41 & $14.81 \%(4 / 27)$ & $15.91 \%(7 / 44)$ & $P<0.05$ \\
\hline K99 & $3.70 \%(1 / 27)$ & $0 \%(0 / 44)$ & - \\
\hline STa & $3.70 \%(1 / 27)$ & $0 \%(0 / 44)$ & - \\
\hline irp2, fyuA & $18.52 \%(5 / 27)$ & $43.18 \%(19 / 44)$ & $P<0.05$ \\
\hline eaeA, Stx1, F41 & $3.70 \%(1 / 27)$ & $0 \%(0 / 44)$ & - \\
\hline F41, K99, STa & $3.70 \%(1 / 27)$ & $0 \%(0 / 44)$ & - \\
\hline irp2, fyuA, Stx1 & $0 \%(0 / 27)$ & $18.18 \%(8 / 44)$ & - \\
\hline hylA, eaeA, Stx 1 & $0 \%(0 / 27)$ & $2.27 \%(1 / 44)$ & - \\
\hline irp2, fyuA, F41 & $0 \%(0 / 27)$ & $4.54 \%(2 / 44)$ & - \\
\hline irp2, F41 & $0 \%(0 / 27)$ & $11.36 \%(5 / 44)$ & - \\
\hline
\end{tabular}

genes, while 11 strains of isolates from dairy cattle carried aac(3')-IIa and sul2 (Table 6).

\section{Frequency of virulence gene occurrence in isolated $E$. coli} strains exhibiting antimicrobial resistance

The frequencies of virulence gene occurrence in isolated E. coli strains exhibiting antimicrobial resistance were detailed in Table 7 . The majority of $\beta$-lactam-, aminoglycoside-, tetracycline-, sulfonamide-, fluoroquinoloneand chloramphenicol-resistant beef cattle $E$. coli isolates (more than 50\%) were positive for irp2 and fyuA genes with a significant association. Significant associations between the rest of virulence genes and antibiotic resistance were not observed.

\section{Discussion}

The emergence and spread of AMR bacteria have become a growing problem and a threat to global public health (WHO 2017). In veterinary practice, penicillin, ampicillin, florfenicol, sulfadiazine, streptomycin, gentamicin and tetracycline are all commonly used antimicrobials for treating $E$. coli-associated infections. Previous studies showed that all $100 \mathrm{E}$. coli isolates from Irish cattle farms were resistant to streptomycin, with a resistance rate of $100 \%$, followed by resistance rates of $99 \%$ for tetracycline, $98 \%$ for sulfonamides, and $82 \%$ for ampicillin (Karczmarczyk et al. 2011). Aasmäe Birgit et al. also reported that the highest proportion of $E$. coli isolates from diseased cattle (clinical submissions) was resistant to streptomycin (Aasmäe et al. 2019). However, in this study, we showed that E. coli isolates from dairy cattle and beef cattle with diarrhea were highly resistant to penicillin. Similar to our results, Barigye Robert et al. reported that 23 of 23 (100\%) virulent isolates from diarrheic neonatal calves were resistant to penicillin (Barigye et al. 2012). In contrast, we found that $E$. coli isolated from beef and dairy cattle were both susceptible to polymyxin B. These results indicated that E. coli with different origins may have undergone different evolutionary processes and thereby acquired different resistance genes. Interestingly, this research showed that the resistance rate of E. coli to antimicrobials (except for florfenicol and polymyxin B) from dairy cattle was higher than that of beef cattle. Multidrug resistance analysis showed that most isolates from dairy cattle and beef cattle were resistant to five or six types of antimicrobials. Similarly, multidrug resistance rate in $E$. coli isolated from dairy cattle is higher than that isolated from beef cattle. In dairy cattle, periodic treatment of mastitis after bacterial infection is very common, and antimicrobials are the most important therapies for bovine mastitis, which may be one potential reason for the high resistance rate of $E$. coli from dairy cattle (Call et al. 2008; Mazurek et al. 2013). Meanwhile, these results suggested that more rational use of antimicrobials in cattle farms was needed to prevent the development of AMR in $E$. coli.

E. coli resistance genes $b l a_{\mathrm{TEM}}$ and $b l a_{\mathrm{SHV}}$ were the first described extended spectrum $\beta$-lactamase (ESBL) genes in the 1980s, and they were predominant until 2000 (Poirel et al. 2018). Currently, the production of ESBL, especially $b l a_{\mathrm{TEM}}$, is one of the most important mechanisms of AMR from the clinical and epidemiological point of view (Poirel et al. 2018). Indeed, previous studies reported that $b l a_{\text {TEM }}$ was detected in $78.94 \%$ isolates from dairy cattle farms in the Nile Delta in Egypt, whereas $b l a_{\mathrm{SHV}}$ and $b l a_{\mathrm{OXA}}$ were detected only in $0.87 \%$ isolates (Braun et al. 2016). In China, previous studies 
Table 5 Beef cattle E. coli resistance genes and virulence genes

\begin{tabular}{|c|c|c|}
\hline Beef cattle strain & Virulence gene & Resistance gene \\
\hline HB150601 & Stxl & bla $a_{\mathrm{TEM}}$, aadAl, tet $(\mathrm{A})$, tet $(\mathrm{B})$, floR \\
\hline HB150605 & hylA, eaeA, Stx1 & blatTEM, sull, aadAl, tet (A), tet (B), floR \\
\hline HB150607 & $\operatorname{irp2}$, fyuA & bla $a_{\mathrm{TEM}}$, aadAl, tet $(\mathrm{A})$, tet $(\mathrm{B})$, floR \\
\hline HB150608 & fyuA & blateM, tet $(\mathrm{A})$, a adA1, tet $(\mathrm{B})$, floR \\
\hline HB150609 & $\operatorname{irp2}$, fyuA & bla $a_{\mathrm{TEM}}$, sull, aadAl, tet (A), tet (B) \\
\hline HB150610 & $\operatorname{irp} 2$, fyuA & bla TEM, sul1, sul2, aac (3')-Ila, aadA1, tet (A), tet (B) \\
\hline HB150611 & irp2, fyuA & blateM, sul1, sul2, aac (3')-Ila, aadA1, tet(A), tet (B), floR \\
\hline HB150614 & $\operatorname{irp2,}$ fyuA & bla ${ }_{\mathrm{TEM}}$, sul2, aadAl, tet (A), tet (B) \\
\hline HB150615 & fyuA & bla \\
\hline HB150616 & fyuA & 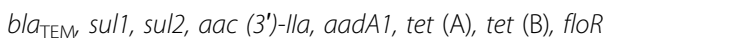 \\
\hline ZD150501 & irp2, fyuA, Stx1 & bla $a_{\mathrm{TEM}}$, sul2, aadAl, tet (A), tet (B) \\
\hline ZD150502 & $\operatorname{irp2,}$ fyuA, Stx 1 & bla ${ }_{\mathrm{TEM}}$, sul2, aadAl, tet (A), tet (B) \\
\hline ZD150503 & $\operatorname{irp2,}$ fyuA, Stx1 & bla ${ }_{\mathrm{TEM}}$, sul2, aadAl, tet $(\mathrm{A})$, tet (B) \\
\hline ZD150504 & $\operatorname{irp} 2$, fyuA, Stx 1 & bla ${ }_{\mathrm{TEM}}$, sul2, aadAl, tet (A), tet (B) \\
\hline ZD150505 & $\operatorname{irp} 2$, fyuA, Stx1 & bla TEM, sul2, aac (3')-Ila, aadAl, tet (A), tet (B), floR \\
\hline ZD150506 & $\operatorname{irp} 2$, fyuA, Stx1 & bla $a_{\mathrm{TEM}}, \operatorname{sul} 2$, aac $\left(3^{\prime}\right)-1 / a, \operatorname{aadA} 1$, tet $(\mathrm{A})$, tet $(\mathrm{B})$ \\
\hline ZD150507 & $\operatorname{irp2,}$ fyuA, Stx1 & bla TEM, sul2, aac( $\left.3^{\prime}\right)-\| l a$, a adAl, tet (A), tet (B) \\
\hline ZD150508 & $\operatorname{irp} 2$, fyuA, Stx1 & bla TEM, sul2, aac (3')-Ila, aadA1, tet (A), tet (B), floR \\
\hline HN150801 & $\operatorname{irp} 2$, fyuA, F41 & 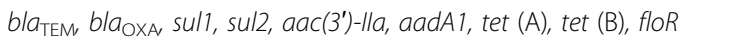 \\
\hline HN150802 & irp2 & 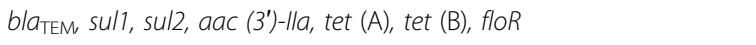 \\
\hline HN150803 & $\operatorname{irp2,F41~}$ & bla TEM, sul1, sul2, aac (3')-Ila, aadA1, tet (A), tet (B), floR \\
\hline HN150804 & $\operatorname{irp2,F41~}$ & 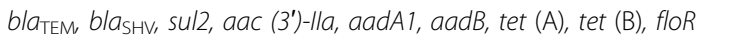 \\
\hline HN150805 & $\operatorname{irp2,F41~}$ & bla $a_{\mathrm{TEM}}$, bla $a_{\mathrm{SHV}}$, sul2, aac (3')-Ila, aadAl, aadB, tet (A), tet (B), floR \\
\hline HN150806 & $\operatorname{irp2}$, fyuA, F41 & 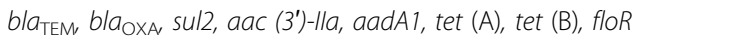 \\
\hline HN150807 & $\operatorname{irp2,F41~}$ & bla ${ }_{\mathrm{TEM}}$, bla $a_{\mathrm{SH}}$, sul1, sul2, aac (3')-Ila, aadA1, aadB, tet (A), tet (B), floR \\
\hline HN150808 & irp2 & bla $a_{\mathrm{SHV}}$, sul2, aac (3')-Ila, aadA1, aadB, tet (A), tet (B), floR \\
\hline HN150809 & irp2 & bla TEM, sul1, sul2, aac (3')-Ha, aadA1, tet (A), tet (B), floR \\
\hline HN150810 & irp2 & bla TEM, bla OXA sul2, aac (3')-Ila, tet (A), tet (B), floR \\
\hline HN150811 & $\operatorname{irp2,} F 41$ & bla $a_{\mathrm{TEM}}, \operatorname{sul} 2$, tet $(\mathrm{A})$, tet $(\mathrm{B})$, floR \\
\hline HN150812 & $\operatorname{irp} 2$, fyuA & bla TEM, sul2, tet $(\mathrm{A})$, tet $(\mathrm{B})$, floR \\
\hline DQ150401 & fyuA & 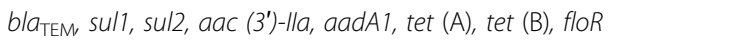 \\
\hline DQ150402 & fyuA & bla TEM, sull, sul2, aac (3')-Ila, aadAl, tet $(\mathrm{A})$, tet $(\mathrm{B})$, floR \\
\hline DQ150403 & fyuA & bla TEM, sul1, sul2, aac (3')-Ila, aadA1, tet (A), tet (B), floR \\
\hline DQ150404 & fyuA & bla TEM, sul1, sul2, aac (3')-Ila, aadA1, tet (A), tet (B), floR \\
\hline DQ150505 & fyuA & blatem, sul1, sul2, aac (3')-Ila, aadAl, tet (A), tet (B), floR \\
\hline DQ150506 & $\operatorname{irp2}$, fyuA & bla TEM, sull, sul2, aac (3')-Ila, aadAl, tet $(\mathrm{A})$, tet $(\mathrm{B})$, floR \\
\hline DQ150507 & irp2, fyuA & bla TEM, sul1, sul2, aac (3')-Ila, aadA1, tet (A), tet (B), floR \\
\hline DQ150508 & $\operatorname{irp} 2$, fyuA & 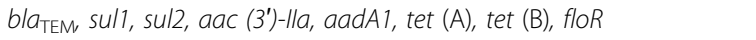 \\
\hline
\end{tabular}

have shown that detection rate of $b l a_{\mathrm{TEM}}$ was the highest (58.7\%); however, detection rate of $b l a_{\mathrm{SHV}}$ was only $2.7 \%$ in dairy cattle farms (Yang et al. 2018). In the present study, 27 E. coli isolates from dairy cattle farms were tested and it was found that detection rate of bla $a_{\text {TEM }}$ was as high as $100 \%$, and detection rates of $b l a_{\mathrm{SHV}}$ and $b l a_{\text {OXA }}$ were also higher than previous studies. Similar to the results in dairy cattle, $44 \mathrm{E}$. coli isolates from beef cattle also showed the highest detection of $b l a_{\mathrm{TEM}}$ (97.7\%). In addition, a previous study reported the resistance rates of $b l a_{\mathrm{SHV}}(0 \%)$ and $b l a_{\mathrm{OXA}}(0 \%)$ in Japanese beef cattle (Yamamoto et al. 2014), while they were 9.1\% 
Table 6 Dairy cattle E. coli resistance genes and virulence genes

\begin{tabular}{|c|c|c|}
\hline Dairy cattle strain & Virulence gene & Resistance gene \\
\hline SH160413 & irp2 & 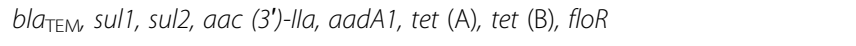 \\
\hline SH160417 & irp2, fyuA & bla TEM, bla OXA bla $a_{\mathrm{SHV}}$, sull, sul2, aac (3')-Ila, aadA1, tet (A), tet (B), tet (C), floR \\
\hline SH160418 & irp2, fyuA & bla TEM, sul1, sul2, aac (3')-Ila, aadA1, tet (A), tet (B), tet (C), floR \\
\hline JS160808 & eaeA, Stx1, F41 & bla TEM, bla OXA, sul2, aac (3')-Ila, tet (A), floR \\
\hline JS160809 & F41, K99, STa & bla $a_{\mathrm{TEM}}, \operatorname{sul} 2$, aac $\left(3^{\prime}\right)-\|_{1}$, tet $(\mathrm{A})$, tet $(\mathrm{B})$ \\
\hline JS160810 & F41 & bla TEM, sul2, aac (3')-Ila, tet (A) \\
\hline JS160811 & F41 & bla TEM, sul2, aac $\left(3^{\prime}\right)-\|_{1}$, tet $(\mathrm{A})$ \\
\hline KD161102 & irp2, fyuA & bla TEM, sul1, sul2, aac (3')-Ila, aadA1, tet (A), tet (B), floR \\
\hline KD161103 & $\operatorname{irp} 2$, fyuA & bla TEM, sul2, aac (3')-Ila, aadA1, tet (A) \\
\hline KD161106 & irp2, fyuA & bla TEM, sull, sul2, aac (3')-Ila, aadAl, tet (A), tet (B), floR \\
\hline KD161108 & fyuA & bla TEM, sul1, sul2, aac (3')-Illa, aadA1, tet (A), floR \\
\hline
\end{tabular}

and $6.8 \%$ in this work, respectively. These results indicated that $b l a_{\text {TEM }}$ was still the most common AMR gene in China and other countries regardless of whether the isolates were from dairy or beef cattle. Furthermore, it is worth noting that detection rates of bla $a_{\mathrm{SHV}}$ and $b l a_{\mathrm{OXA}}$ may have a tendency to increase. This research further showed that chloramphenicol and aminoglycoside resistance genes were present in $E$. coli isolates. Detection rates of $f l o R$ in dairy cattle and beef cattle were $96.3 \%$ and $59.1 \%$, respectively, which were similar to previous reports (Belaynehe et al. 2018; Wu et al. 2011). In addition, aminoglycoside (resistance) genes aadA1 and $a a d B$ were detected in $70.4 \%$ and $0 \%$ of $27 \mathrm{E}$. coli isolates from dairy cattle and in $100 \%$ and $9.1 \%$ of 44 E. coli isolates from beef cattle. In Ireland, aadA1 and $a a d B$ were identified in $19 \%$ and $1 \%$ of 100 (MDR) E. coli isolates recovered from dairy cattle (Karczmarczyk et al. 2011). In Iran, aadA1 was detected in $26.2 \%$ of $E$. coli isolates from dairy cattle (Jamali et al. 2018). In Mexico, aadA1 was detected in $17 \%$ of E. coli isolates from beef cattle (Martínez-Vázquez et al. 2018). Detection rate of $\operatorname{aad} A 1$ in this study is much higher than that reported in other countries. Interestingly, the detection rate of aac(3')-IIa that has not been reported in previous studies was $56.8 \%$ in beef cattle and $96.3 \%$ in dairy cattle, which is worth further investigation detection rate of tetracycline resistance gene tet (A) was $97.7 \%$, followed by tet (B) $(95.5 \%)$ and tet (C) (0\%) in 44 E. coli isolates from beef cattle. In isolates from dairy cattle, detection rate of tet (A) was $96.33 \%$, followed by tet (B) $(70.4 \%)$ and tet (C) (7.4\%). sul1 gene was detected in $40.7 \%$ and $47.7 \%$ while sul2 gene was detected in $96.3 \%$ and $77.3 \%$ of E. coli isolates from dairy cattle and beef cattle, respectively. These results are similar to those previously reported data (Karczmarczyk et al. 2011; Belaynehe et al. 2018; Shin et al. 2015; Navajas-Benito et al. 2017). Further analysis found that the overall detection rate of resistance genes in dairy cattle was higher than that of beef cattle, suggesting the widespread resistance of $E$. coli in dairy cattle.

Totally 14 different virulence genes were analyzed in E. coli isolates from dairy cattle and beef cattle. However, only 7 diarrheagenesis-associated virulence genes (irp2, fyuA, stx1, eaeA, F41, K99 and STa) were detected in isolates from dairy cattle, and 6 diarrheagenesisassociated virulence genes (irp2, fyuA, Stx1, eaeA, hylA and F41) were detected in isolates from beef cattle. In beef cattle, 28 out of $44 \mathrm{E}$. coli isolates were positive for irp2 (63.64\%), and 27 were positive for fyuA (61.36\%). Detection rates of irp 2 and $f y u A$ in isolates from dairy cattle were also the highest, both at $22.22 \%$. These results suggested that irp2 and fyuA in E. coli isolates from dairy cattle and beef cattle were the main virulence genes, which was similar to the results of previous studies (Ewers et al. 2004; de Verdier et al. 2012). The results also indicated that detection rate of the main virulence genes irp 2 and $f y u A$ in isolates from beef cattle was higher than that in isolates from dairy cattle. Furthermore, detection rates of $F 41$ and eaeA genes were not significantly different between beef and dairy cattle, which was consistent with the results of previous peports (Andrade et al. 2012; Hornitzky et al. 2005; Fremaux et al. 2006). However, the percentage of stx1-positive isolates was higher in beef cattle $(22.73 \%)$ than in dairy cattle $(3.7 \%)$, which was different from the results of a previous study (Bok et al. 2015). Further analysis showed that detection rate of irp2/fyuA combination in $E$. coli isolates from beef cattle was also higher than that in dairy cattle. Interestingly, irp 2/ fyuA/Stx1, hylA/eaeA/Stx1, irp2/fyuA/F41 and irp2/ F41 combinations were not detected in dairy cattle but were detected in beef cattle. These results lay a foundation for further understanding the distribution of virulence genes in $E$. coli isolated from dairy cattle and beef cattle and provide a basis for reducing $E$. coli infections. 
Table 7 Frequency of virulence genes among antibiotic-resistant E. coli isolates

\begin{tabular}{|c|c|c|c|c|c|c|c|c|c|c|c|c|c|}
\hline \multirow{2}{*}{$\begin{array}{l}\text { Antibiotic } \\
\text { resistance } \\
\text { (beef and } \\
\text { dairy } \\
\text { cattle) }\end{array}$} & \multicolumn{6}{|c|}{$\begin{array}{l}\text { Beef cattle } E \text {. coli carry virulence genes } \\
\text { n (\%) }\end{array}$} & \multicolumn{7}{|c|}{$\begin{array}{l}\text { Dairy cattle } E \text {. coli carry virulence genes } \\
\mathrm{n}(\%)\end{array}$} \\
\hline & Irp2 & fyuA & Stx 1 & F41 & hylA & $e a e A$ & Irp2 & fyuA & F41 & Stx 1 & eaeA & $K 99$ & STa \\
\hline PEN & $28 / 43$ & $27 / 43$ & $10 / 43$ & $7 / 43$ & $1 / 43$ & $1 / 43$ & $6 / 27$ & $6 / 27$ & $4 / 27$ & $1 / 27$ & $1 / 27$ & $1 / 27$ & $1 / 27$ \\
\hline (43) and (27) & $65.1 \%$ & $62.8 \%$ & $23.3 \%$ & $16.9 \%$ & $0.02 \%$ & $0.02 \%$ & $22.2 \%$ & $22.2 \%$ & $14.8 \%$ & $3.7 \%$ & $3.7 \%$ & $3.7 \%$ & $3.7 \%$ \\
\hline AMC & $18 / 24$ & $13 / 24$ & $4 / 24$ & $7 / 24$ & $0 / 24$ & $0 / 24$ & $6 / 22$ & $5 / 22$ & $4 / 22$ & $1 / 22$ & $1 / 22$ & $1 / 22$ & $1 / 22$ \\
\hline (24) and (22) & $75 \%$ & $54.2 \%$ & $16.7 \%$ & $25.9 \%$ & $0 \%$ & $0 \%$ & $27.3 \%$ & $22.7 \%$ & $18.2 \%$ & $0.05 \%$ & $0.05 \%$ & $0.05 \%$ & $0.05 \%$ \\
\hline AMP & $25 / 38$ & $22 / 38$ & $7 / 38$ & $7 / 38$ & $1 / 38$ & $1 / 38$ & $6 / 26$ & $5 / 26$ & $4 / 26$ & $1 / 22$ & $1 / 22$ & $1 / 22$ & $1 / 22$ \\
\hline (38) and (26) & $65.8 \%$ & $57.9 \%$ & $18.4 \%$ & $18.4 \%$ & $0.03 \%$ & $0.03 \%$ & $23.1 \%$ & $19.2 \%$ & $15.4 \%$ & $0.05 \%$ & $0.05 \%$ & $0.05 \%$ & $0.05 \%$ \\
\hline CFZ & $17 / 21$ & $11 / 21$ & $3 / 21$ & $7 / 21$ & $0 / 21$ & $0 / 21$ & $4 / 19$ & $4 / 19$ & $4 / 19$ & $1 / 22$ & $1 / 22$ & $1 / 22$ & $1 / 22$ \\
\hline (21) and (19) & $80.9 \%$ & $52.4 \%$ & $14.3 \%$ & $33.3 \%$ & $0 \%$ & $0 \%$ & $21.1 \%$ & $21.1 \%$ & $21.1 \%$ & $0.05 \%$ & $0.05 \%$ & $0.05 \%$ & $0.05 \%$ \\
\hline STR & $16 / 22$ & $12 / 22$ & $4 / 22$ & $7 / 20$ & $0 / 18$ & $0 / 18$ & $4 / 18$ & $4 / 18$ & $4 / 18$ & $1 / 22$ & $1 / 22$ & $1 / 22$ & $1 / 22$ \\
\hline (22) and (18) & $72.7 \%$ & $54.5 \%$ & $18.2 \%$ & $35 \%$ & $0 \%$ & $0 \%$ & $22.2 \%$ & $22.2 \%$ & $22.2 \%$ & $0.05 \%$ & $0.05 \%$ & $0.05 \%$ & $0.05 \%$ \\
\hline GEN & $16 / 20$ & $11 / 20$ & $4 / 20$ & $6 / 20$ & $0 / 20$ & $0 / 20$ & $3 / 17$ & $2 / 17$ & $0 / 17$ & $0 / 17$ & $0 / 17$ & $0 / 17$ & $0 / 17$ \\
\hline (20) and (17) & $80 \%$ & $55 \%$ & $20 \%$ & $30 \%$ & $0 \%$ & $0 \%$ & $17.6 \%$ & $11.8 \%$ & $0 \%$ & $0 \%$ & $0 \%$ & $0 \%$ & $0 \%$ \\
\hline KAN & $14 / 19$ & $11 / 19$ & $4 / 19$ & $6 / 19$ & 0/19 & $0 / 19$ & $2 / 12$ & $2 / 12$ & $3 / 12$ & $0 / 12$ & $0 / 12$ & $1 / 22$ & $1 / 22$ \\
\hline (19) and (12) & $73.7 \%$ & $57.9 \%$ & $21.1 \%$ & $31.6 \%$ & $0 \%$ & $0 \%$ & $16.7 \%$ & $16.7 \%$ & $25 \%$ & $0 \%$ & $0 \%$ & $0.05 \%$ & $0.05 \%$ \\
\hline TET & $22 / 31$ & $17 / 31$ & $7 / 31$ & $7 / 31$ & $1 / 31$ & $1 / 31$ & $6 / 21$ & $5 / 21$ & $4 / 21$ & $1 / 21$ & $1 / 21$ & $1 / 21$ & $1 / 21$ \\
\hline (31) and (21) & $70.9 \%$ & $54.8 \%$ & $22.6 \%$ & $22.6 \%$ & $0.03 \%$ & $0.03 \%$ & $28.6 \%$ & $23.8 \%$ & $19 \%$ & $0.05 \%$ & $0.05 \%$ & $0.05 \%$ & $0.05 \%$ \\
\hline $\mathrm{COM}$ & $18 / 26$ & $14 / 26$ & $4 / 26$ & $7 / 26$ & $0 / 26$ & $0 / 26$ & $5 / 21$ & $5 / 21$ & $4 / 21$ & $1 / 21$ & $1 / 21$ & $1 / 21$ & $1 / 21$ \\
\hline (26) and (21) & $69.2 \%$ & $53.8 \%$ & $15.9 \%$ & $26.9 \%$ & $0 \%$ & $0 \%$ & $23.8 \%$ & $23.8 \%$ & $19 \%$ & $0.05 \%$ & $0.05 \%$ & $0.05 \%$ & $0.05 \%$ \\
\hline SULF & $20 / 30$ & $16 / 30$ & $5 / 30$ & $7 / 30$ & $1 / 30$ & $1 / 30$ & $6 / 22$ & $6 / 22$ & $4 / 22$ & $1 / 22$ & $1 / 22$ & $1 / 22$ & $1 / 22$ \\
\hline (30) and (22) & $66.7 \%$ & $53.3 \%$ & $16.7 \%$ & $23.3 \%$ & $0.03 \%$ & $0.03 \%$ & $27.3 \%$ & $27.3 \%$ & $18.2 \%$ & $0.05 \%$ & $0.05 \%$ & $0.05 \%$ & $0.05 \%$ \\
\hline CIP & $18 / 22$ & $12 / 22$ & $4 / 22$ & $6 / 22$ & $0 / 22$ & $0 / 22$ & $4 / 18$ & $3 / 18$ & $4 / 18$ & $0 / 18$ & $1 / 18$ & $1 / 18$ & $1 / 18$ \\
\hline (22) and (18) & $81.8 \%$ & $54.5 \%$ & $18.2 \%$ & $27.3 \%$ & $0 \%$ & $0 \%$ & $22.2 \%$ & $16.7 \%$ & $22.2 \%$ & $0 \%$ & $0.06 \%$ & $0.06 \%$ & $0.06 \%$ \\
\hline ENR & $18 / 23$ & $12 / 23$ & $4 / 23$ & $7 / 23$ & $0 / 23$ & $0 / 23$ & $4 / 17$ & $3 / 17$ & $3 / 17$ & $1 / 17$ & $0 / 17$ & $1 / 17$ & $1 / 17$ \\
\hline (23) and (17) & $78.3 \%$ & $52.1 \%$ & $17.4 \%$ & $30.4 \%$ & $0 \%$ & $0 \%$ & $23.5 \%$ & $17.6 \%$ & $17.6 \%$ & $0.06 \%$ & $0 \%$ & $0.06 \%$ & $0.06 \%$ \\
\hline OFX & $17 / 19$ & $13 / 19$ & $4 / 19$ & $6 / 19$ & $0 / 19$ & 0/19 & $3 / 17$ & $3 / 17$ & $3 / 17$ & $0 / 17$ & $0 / 17$ & $0 / 17$ & $0 / 17$ \\
\hline (19) and (17) & $89.5 \%$ & $68.4 \%$ & $21.1 \%$ & $31.6 \%$ & $0 \%$ & $0 \%$ & $17.6 \%$ & $17.6 \%$ & $17.6 \%$ & $0 \%$ & $0 \%$ & $0 \%$ & $0 \%$ \\
\hline FFC & $12 / 17$ & $7 / 17$ & $2 / 17$ & $7 / 17$ & $0 / 17$ & $0 / 17$ & $2 / 9$ & $2 / 9$ & $1 / 9$ & $1 / 9$ & $1 / 9$ & 0/9 & $0 / 9$ \\
\hline (17) and (9) & $70.6 \%$ & $41.2 \%$ & $11.8 \%$ & $41.2 \%$ & $0 \%$ & $0 \%$ & $22.2 \%$ & $22.2 \%$ & $11.1 \%$ & $11.1 \%$ & $11.1 \%$ & $0 \%$ & $0 \%$ \\
\hline PB & $0 / 1$ & $1 / 1$ & $0 / 1$ & $0 / 1$ & $0 / 1$ & $0 / 1$ & $0 / 0$ & 0/0 & $0 / 0$ & 0/0 & $0 / 0$ & 0/0 & 0/0 \\
\hline (1) and (0) & $0 \%$ & $100 \%$ & $0 \%$ & $0 \%$ & $0 \%$ & $0 \%$ & $0 \%$ & $0 \%$ & $0 \%$ & $0 \%$ & $0 \%$ & $0 \%$ & $0 \%$ \\
\hline
\end{tabular}

Note: $\beta$-lactams: penicillin (PEN), amoxicillin (AMC), ampicillin (AMP), and cefazolin (CFZ); aminoglycosides: streptomycin (STR), gentamicin (GEN), and kanamycin (KAN); tetracyclines: tetracycline (TET); sulfonamides: compound sulfamethoxydiazine (SULF); fluoroquinolones: ciprofloxacin (CIP), enrofloxacin (ENR), and ofloxacin (OFX); chloramphenicol: florfenico (FFC); polypeptides: polymyxin B (PB)

\section{Conclusions}

The results of this study indicated that MDR diarrheagenic E. coli were more common in dairy and beef calves, with frequent MDR, ESBL and the presence of tetracycline resistance gene tet (A). The prevalence rate in dairy cattle is higher than that in beef cattle, which may be related to the prevalence of resistance genes and highlights the importance of the rational use of antimicrobials and strict enforcement of preventive measures in cattle farms. Furthermore, detection rate of virulence genes in the isolates from dairy cattle was lower than that in beef cattle. Although the link between resistance and virulence genes has been extensively studied and virulence genes $\operatorname{irp} 2$ and $f y u A$ have a high detection rate in MDR strains, it is still not conclusive. Our results provide important evidences for better exploring their interaction mechanism. Further studies are also needed to understand the origin and transmission route of $E$. coli in cattle to reduce its prevalence. 
Table 8 Primers of antimicrobial resistance genes and virulence genes

\begin{tabular}{|c|c|c|c|c|c|}
\hline Classification & Gene & Primer sequence $\left(5^{\prime} \rightarrow 3^{\prime}\right)$ & Annealing temperature & Fragment length & Reference \\
\hline \multirow[t]{3}{*}{$\bar{\beta}$-lactams } & $b l a_{\mathrm{OXA}}$ & $\begin{array}{l}\text { F:TTTCTGTTGTTTGGGTTC } \\
\text { R:TTCTTGGCTTTATGCTTG }\end{array}$ & $53^{\circ} \mathrm{C}$ & $447 \mathrm{bp}$ & This work \\
\hline & $b^{b} a_{\mathrm{SHV}}$ & $\begin{array}{l}\text { F:TGTATTATCTCCCTGTTAGC } \\
\text { R:TTAGCGTTGCCAGTGCTC }\end{array}$ & $55^{\circ} \mathrm{C}$ & $843 \mathrm{bp}$ & \\
\hline & bla & $\begin{array}{l}\text { F:CAGAAACGCTGGTGAAAG } \\
\text { R:TTACCAATGGTTAATCAGTGAG }\end{array}$ & $54^{\circ} \mathrm{C}$ & $788 \mathrm{bp}$ & \\
\hline \multirow[t]{3}{*}{ Tetracyclines } & tet $(\mathrm{A})$ & $\begin{array}{l}\text { F:GCTACATCCTGCTTGCCTTC } \\
\text { R:CATAGATCGCCGTGAAGAGG }\end{array}$ & $59.5^{\circ} \mathrm{C}$ & $210 \mathrm{bp}$ & Ng et al. 2001 \\
\hline & tet (B) & $\begin{array}{l}\text { F:TTGGTTAGGGGCAAGTITGG } \\
\text { R:GTAATGGGCCAATAACACCG }\end{array}$ & $59.5^{\circ} \mathrm{C}$ & $659 \mathrm{bp}$ & \\
\hline & tet $(\mathrm{C})$ & $\begin{array}{l}\text { F:CTTGAGAGCCTTCAACCCAG } \\
\text { R:ATGGTCGTCATCTACCTGCC }\end{array}$ & $59.5^{\circ} \mathrm{C}$ & $418 \mathrm{bp}$ & \\
\hline \multirow[t]{2}{*}{ Sulfonamides } & sul1 & $\begin{array}{l}\text { F:TCGGACAGGGCGTCTAAG } \\
\text { R:GGGTATCGGAGCGTTTC }\end{array}$ & $63^{\circ} \mathrm{C}$ & $925 \mathrm{bp}$ & This work \\
\hline & sul2 & $\begin{array}{l}\text { F:CTTGTTCGTCCGACACAGA } \\
\text { R:GAAGCGCAGCCGCAATTCAT }\end{array}$ & $60^{\circ} \mathrm{C}$ & $435 \mathrm{bp}$ & \\
\hline \multirow[t]{3}{*}{ Aminoglycosides } & $\operatorname{aadA1}$ & $\begin{array}{l}\text { F:GCAGCGCAATGACATTCTTG } \\
\text { R:ATCCTCGGCGCGATTTTG }\end{array}$ & $60^{\circ} \mathrm{C}$ & $282 \mathrm{bp}$ & Sáenz et al. 2004 \\
\hline & $a a d B$ & $\begin{array}{l}\text { F:GAGGAGTTGGACTATGGATT } \\
\text { R:CTTCATCGGCATAGTAAAA }\end{array}$ & $53^{\circ} \mathrm{C}$ & $208 \mathrm{bp}$ & This work \\
\hline & $a a c\left(3^{\prime}\right)-1 / a$ & $\begin{array}{l}\text { F:GGCGACTTCACCGTTTCT } \\
\text { R: GGACCGATCACCCTACGAG }\end{array}$ & $54^{\circ} \mathrm{C}$ & $412 \mathrm{bp}$ & \\
\hline Chloramphenicols & floR & $\begin{array}{l}\text { F: GAACACGACGCCCGCTAT } \\
\text { R: TTCCGCTTGGCCTATGAG }\end{array}$ & $54^{\circ} \mathrm{C}$ & $601 \mathrm{bp}$ & This work \\
\hline \multirow{2}{*}{$\begin{array}{l}\text { Yersinia } \\
\text { High } \\
\text { Pathogenicity Island }\end{array}$} & irp2 & $\begin{array}{l}\text { F:AAGGATTCGCTGTTACCGGA } \\
\text { R:TCGGCCAGGATGATTCGTCG }\end{array}$ & $60^{\circ} \mathrm{C}$ & $301 \mathrm{bp}$ & This work \\
\hline & fyuA & $\begin{array}{l}\text { F:ACACGGCTTATCCTCTGGC } \\
\text { R:GGCATCTTGACGATTAACGAA }\end{array}$ & $58^{\circ} \mathrm{C}$ & $953 \mathrm{bp}$ & This work \\
\hline Intimin & eaeA & $\begin{array}{l}\text { F:ATTACTGAGATTAAGGCTGAT } \\
\text { R:ATTTATTTGCAGCCCCCCAT }\end{array}$ & $57^{\circ} \mathrm{C}$ & $682 \mathrm{bp}$ & This work \\
\hline \multirow[t]{5}{*}{ Fimbriae } & $F 41$ & $\begin{array}{l}\text { F:GAGGGACTTCATCTTTTAG } \\
\text { R:AGTCCATTCCATTATAGGC }\end{array}$ & $58^{\circ} \mathrm{C}$ & $431 \mathrm{bp}$ & This work \\
\hline & K88 & $\begin{array}{l}\text { F:GCTGCATCTGCTGCATCTGGTATG } \\
\text { R:CCACTGAGTGCTGGTAGTTACAGCC }\end{array}$ & $60^{\circ} \mathrm{C}$ & 792 bp & This work \\
\hline & K99 & $\begin{array}{l}\text { F:TATTATCTTAGGTGGTATGG } \\
\text { R:GGTATCCTITAGCAGCAGTATTTC }\end{array}$ & $56^{\circ} \mathrm{C}$ & $314 \mathrm{bp}$ & This work \\
\hline & $987 P$ & $\begin{array}{l}\text { F:TCTGCTCTTAAAGCTACTGG } \\
\text { R:AACTCCACCGTTTGTATCAG }\end{array}$ & $55.8^{\circ} \mathrm{C}$ & $333 \mathrm{bp}$ & This work \\
\hline & F18 & $\begin{array}{l}\text { F:GTGAAAAGACTAGTGTTAATTC } \\
\text { R:CTTGTAAGTAACCGCGTAAGC }\end{array}$ & $55^{\circ} \mathrm{C}$ & $510 \mathrm{bp}$ & This work \\
\hline Hemolysin & hylA & $\begin{array}{l}\text { F:GCATCATCAAGCGTACGTTCC } \\
\text { R:AATGAGCCAAGCTGGTTAAGCT }\end{array}$ & $60^{\circ} \mathrm{C}$ & $534 \mathrm{bp}$ & This work \\
\hline \multirow[t]{2}{*}{ Shiga toxins } & Stx 1 & $\begin{array}{l}\text { F:TTAGACTTCTCGACTGCAAAG } \\
\text { R:TGTTGTACGAAATCCCCTCTG }\end{array}$ & $52^{\circ} \mathrm{C}$ & $531 \mathrm{bp}$ & This work \\
\hline & Stx2 & $\begin{array}{l}\text { F:CCATGACAACGGACAGCAGTT } \\
\text { R:CCTGTCAACTGAGCAGCACTTTG }\end{array}$ & $58^{\circ} \mathrm{C}$ & $779 \mathrm{bp}$ & This work \\
\hline \multirow[t]{2}{*}{ Heat-stable enterotoxins } & STa & $\begin{array}{l}\text { F:TCCCCTCTITAGTCAGTCAACTG } \\
\text { R:GCACAGGCAGGATTACAACAAAGT }\end{array}$ & $56^{\circ} \mathrm{C}$ & $163 \mathrm{bp}$ & This work \\
\hline & $S T b$ & $\begin{array}{l}\text { F:GCAATAAGGTTGAGGTGAT } \\
\text { R:GCCTGCAGTGAGAAATGGAC }\end{array}$ & $60^{\circ} \mathrm{C}$ & $368 \mathrm{bp}$ & This work \\
\hline Heat-labile enterotoxins & $L T$ & $\begin{array}{l}\text { F:GGCGACAGATTATACCGTGC } \\
\text { R:CGGTCTCTATATTCCCTGTT }\end{array}$ & $54^{\circ} \mathrm{C}$ & $450 \mathrm{bp}$ & This work \\
\hline
\end{tabular}




\section{Materials and methods}

\section{Sample collection and identification of $E$. coli}

From April 2016 to November 2018, we collected fecal samples from sick dairy calves with diarrhea in Suihua, Jiusan and Kedong and fecal samples from sick beef calves in Harbin, Zhaodong and Daqing in Heilongjiang Province, China. The aseptically collected intestinal and fecal samples were inoculated onto MacConkey agar and eosin methylene blue agar (Momtaz et al. 2013a, b). After overnight incubation at $37^{\circ} \mathrm{C}$, only pure pink colonies were selected and transferred to nutrient agar. The isolate was identified by $16 \mathrm{~S}$ rDNA and stored in $50 \%$ glycerol at $-80^{\circ} \mathrm{C}$.

\section{Antimicrobial susceptibility test}

The antimicrobial susceptibility of $E$. coli isolated from diarrheal dairy cattle and beef cattle was tested using the KirbyBauer disk diffusion method according to standards of the Clinical and Laboratory Standards Association (Clinical and Laboratory Standards Institute 2014). Nutrient agar was used to determine the susceptibility of $E$. coli to 15 different antimicrobials using commercial disks: penicillin (PEN, $10 \mu \mathrm{g}$ ), amoxicillin (AMC, $10 \mu \mathrm{g}$ ), ampicillin (AMP, $10 \mu \mathrm{g}$ ), cefazolin (CFZ, $30 \mu \mathrm{g}$ ), streptomycin (STR, $10 \mu \mathrm{g}$ ), gentamicin (GEN, $10 \mu \mathrm{g})$, kanamycin (KAN, $30 \mu \mathrm{g})$, polymyxin $\mathrm{B}(\mathrm{PB}, 300$ units), tetracycline (TET, $30 \mu \mathrm{g})$, compound sulfamethoxazole (COM, 23.75/1.25 $\mu \mathrm{g}$ ), sulfamethoxydiazine (SULF, $5 \mu \mathrm{g}$ ), florfenico (FFC, $30 \mu \mathrm{g}$ ), ciprofloxacin (CIP, $5 \mu \mathrm{g}$ ), enrofloxacin (ENR, $5 \mu \mathrm{g}$ ), and ofloxacin (OFX, $5 \mu \mathrm{g}$ ). Laboratorystored E. coli ATCC 25922 was used as a control strain.

\section{DNA extraction and amplification of resistance genes and} virulence genes

Primers used to amplify resistance genes (bla $a_{\mathrm{TEM}}$, bla $a_{\mathrm{SHV}}, b l a_{\mathrm{OXA}}$, tet (A), tet (B), tet (C), sul1, sul2, aadA1, $\operatorname{aadB}$ and $\operatorname{aac}\left(3^{\prime}\right)-I I a$, floR) and virulence genes (irp2, fyuA, eaeA, hylA, K88, K99, F41, 987P, F18, Stx1, Stx2, Sta, Stb and $L T$ ) were shown in Table 8. Primers were synthesized by the Shanghai Bioengineering Co., Ltd. E. coli genomic DNA was extracted according to the manufacturer's instructions of the extraction kit (Beijing Tiangen Biotechnology Co., Ltd.). PCR was carried out in a $25 \mu \mathrm{L}$ volume containing $12.5 \mu \mathrm{L}$ of $2 \times$ Taq MasterMix (ComWin Biotech Co., Ltd., Beijing, China), $1 \mu \mathrm{L}$ of forward and reverse primer, $1 \mu \mathrm{L}$ of DNA template and $9.5 \mu \mathrm{L}$ of $\mathrm{ddH}_{2} \mathrm{O}$. The parameters for PCR included an initial annealing at $95^{\circ} \mathrm{C}$ for $5 \mathrm{~min}$ and 30 cycles of $94^{\circ} \mathrm{C}$ for $30 \mathrm{~s}, 53-63^{\circ} \mathrm{C}$ for $45 \mathrm{~s}$ (the annealing temperature varied according to the primers), and $72{ }^{\circ} \mathrm{C}$ for $60 \mathrm{~s}$, followed by a final extension at $72{ }^{\circ} \mathrm{C}$ for $5 \mathrm{~min}$. PCR products were analyzed by electrophoresis in a $1 \%$ agarose gel.

\section{Statistical analysis}

All statistical analyses were performed using GraphPad Prism $^{\ominus} 8.00$ software (GraphPad Software, Inc., USA). For all experiments, differences were considered to be statistically significant at $P<0.05$ values.

\section{Abbreviations}

E. coli: Escherichia coli; MDR: Multidrug resistant; DEC: Diarrheagenic E. coli; AMR: Antimicrobial resistance; STEC: Shiga-toxin producing E. coli; PEN: Penicillin; AMC: Amoxicillin; AMP: Ampicillin; CFZ: Cefazolin; STR: Streptomycin; GEN: Gentamicin; KAN: Kanamycin; TET: Tetracycline; COM: Compound sulfamethoxazole; SULF: Sulfamethoxydiazine; CIP: Ciprofloxacin; ENR: Enrofloxacin; OFX: Ofloxacin; FFC: Florfenico; PB: Polymyxin B; ESBL: Extended spectrum $\beta$-lactamases

\section{Acknowledgments}

We would like to thank the Editage (http://www.editage.cn) for English language editing.

\section{Authors' contributions}

S.Y., Y.Z., and Z.Z. contributed to the conception and design of this work; S.Y., C.W., W.H., and N.C. participated in sample collection, laboratory experiments and data analysis; S.Y and Y.L. drafted the manuscript; and S.Y., Z.Z., Y.L., and $Z$ Z.Z. revised the manuscript. All authors have read and approved the final version of the manuscript.

\section{Funding}

This study was supported by the National Science and Technology Ministry (2014BAD13B03-1) and the project supported by the Heilongjiang Province Farms General Administration of China (HNK135-04-03). This work was supported by a grant from the Heilongjiang Bayi Agricultural University Support Program for San Heng San Zong (TDJH202002).

Availability of data and materials

All data can be shared upon reasonable request. The data can be obtained by email.

\section{Declarations}

Ethics approval and consent to participate

Not applicable.

Consent for publication

Not applicable.

\section{Competing interests}

The authors declare no conflicts of interest.

\section{Author details}

${ }^{1}$ College of Animal Science and Veterinary Medicine, Heilongjiang Bayi Agricultural University, Daqing 163319, China. ${ }^{2}$ Heilongjiang Provincial Technology Innovation Center for Bovine Disease Control and Prevention, Daqing 163319, China. ${ }^{3}$ Heilongjiang Provincial Key Laboratory of Prevention and Control of Bovine Diseases, Daqing 163319, China. ${ }^{4}$ Heilongjiang Province Cultivating Collaborative Innovation Center for The Beidahuang Modern Agricultural Industry Technology, Daqing 163319, China.

Received: 28 April 2021 Accepted: 1 August 2021

Published online: 03 September 2021

\section{References}

Aasmäe, B., L. Häkkinen, T. Kaart, and P. Kalmus. 2019. Antimicrobial resistance of Escherichia coli and Enterococcus spp. isolated from Estonian cattle and swine from 2010 to 2015. Acta Veterinaria Scandinavica 61 (1): 5. https://doi.org/1 0.1186/s13028-019-0441-9.

Andrade, G.I., F.M. Coura, E.L.S. Santos, M.G. Ferreira, G.C.F. Galinari, E.J. Facury Filho, A.U. Carvalho, A.P. Lage, and M.B. Heinemann. 2012. Identification of virulence factors by multiplex PCR in Escherichia coli isolated from calves in Minas Gerais, Brazil. Tropical Animal Health and Production 44 (7): 1783-1790. https://doi.org/10.1007/s11250-012-0139-8. 
Anes, J., S.V. Nguyen, A.K. Eshwar, E. McCabe, G. Macori, D. Hurley, A. Lehner, and S. Fanning. 2020. Molecular characterisation of multi-drug resistant Escherichia coli of bovine origin. Veterinary Microbiology 242: 108566. https:// doi.org/10.1016/j.vetmic.2019.108566.

Barigye, R., A. Gautam, L.M. Piche, L.P. Schaan, D.F. Krogh, and S. Olet. 2012. Prevalence and antimicrobial susceptibility of virulent and avirulent multidrug-resistant Escherichia coli isolated from diarrheic neonatal calves. American Journal of Veterinary Research 73 (12): 1944-1950. https://doi.org/1 0.2460/ajvr.73.12.1944

Belaynehe, K.M., S.W. Shin, and H.S. Yoo. 2018. Interrelationship between tetracycline resistance determinants, phylogenetic group affiliation and carriage of class 1 integrons in commensal Escherichia coli isolates from cattle farms. BMC Veterinary Research 14 (1): 340. https://doi.org/10.1186/s12 917-018-1661-3.

Bok, E., J. Mazurek, M. Stosik, M. Wojciech, and K. Baldy-Chudzik. 2015. Prevalence of virulence determinants and antimicrobial resistance among commensal Escherichia coli derived from dairy and beef cattle. International Journal of Environmental Research and Public Health 12 (1): 970-985. https://doi.org/1 0.3390/ijerph120100970.

Braun, S.D., M.F.E. Ahmed, H. El-Adawy, H. Hotzel, I. Engelmann, D. Weiß, S. Monecke, and R. Ehricht. 2016. Surveillance of extended-spectrum beta-lactamaseproducing Escherichia coli in dairy cattle farms in the Nile delta, Egypt. Frontiers in Microbiology 7: 1020. https://doi.org/10.3389/fmicb.2016.01020.

Call, D.R., M.A. Davis, and A.A. Sawant. 2008. Antimicrobial resistance in beef and dairy cattle production. Animal Health Research Reviews 9 (2): 159-167. https://doi.org/10.1017/S1466252308001515.

Cazer, C.L., L. Ducrot, V.V. Volkova, and Y.T. Gröhn. 2017. Monte Carlo simulations suggest current chlortetracycline drug-residue based withdrawal periods would not control antimicrobial resistance dissemination from feedlot to slaughterhouse. Frontiers in Microbiology 8: 1753. https://doi.org/10.3389/ fmicb.2017.01753.

Clinical and Laboratory Standards Institute (CLSI). 2014. Performance standards for antimicrobial susceptibility testing. Twenty-First Informational Supplement. CLSI/ NCCLS-M100-S24. Wayne: Clinical and Laboratory Standards Institute.

Croxen, M.A., and B. Brett Finlay. 2010. Molecular mechanisms of Escherichia coli pathogenicity. Nature Reviews Microbiology 8 (1): 26-38. https://doi.org/10.103 8/nrmicro2265.

de Moyaert, H., A. de Jong, S. Simjee, and V. Thomas. 2014. Antimicrobial resistance monitoring projects for zoonotic and indicator bacteria of animal origin: Common aspects and differences between EASSA and EFSA. Veterinary Microbiology 171 (3/4): 279-283. https://doi.org/10.1016/j.vetmic.2 014.02.038.

de Verdier, K., A. Nyman, C. Greko, and B. Bengtsson. 2012. Antimicrobial resistance and virulence factors in Escherichia coli from Swedish dairy calves. Acta Veterinaria Scandinavica 54 (1): 2. https://doi.org/10.1186/1751-014754-2. [PubMed].

Diarra, M.S., K. Giguère, F. Malouin, B. Lefebvre, S. Bach, P. Delaquis, M. Aslam, K.A. Ziebell, and G. Roy. 2009. Genotype, serotype, and antibiotic resistance of sorbitol-negative Escherichia coli isolates from feedlot cattle. Journal of Food Protection 72 (1): 28-36. https://doi.org/10.4315/0362-028x-72.1.28.

Ewers, C., C. Schüffner, R. Weiss, G. Baljer, and L.H. Wieler. 2004. Molecular characteristics of Escherichia coli serogroup 078 strains isolated from diarrheal cases in bovines urge further investigations on their zoonotic potential. Molecular Nutrition \& Food Research 48 (7): 504-514. https://doi. org/10.1002/mnfr.200400063.

Fremaux, B., S. Raynaud, L. Beutin, and C.V. Rozand. 2006. Dissemination and persistence of Shiga toxin-producing Escherichia coli (STEC) strains on French dairy farms. Veterinary Microbiology 117 (2/3/4): 180-191. https://doi.org/10.1 016/j.vetmic.2006.04.030.

Fröhlicher, E., G. Krause, C. Zweifel, L. Beutin, and R. Stephan. 2008. Characterization of attaching and effacing Escherichia coli (AEEC) isolated from pigs and sheep. BMC Microbiology 8 (1): 144. https://doi.org/10.1186/14 71-2180-8-144

Hornitzky, M.A., K. Mercieca, K.A. Bettelheim, and S.P. Djordjevic. 2005. Bovine feces from animals with gastrointestinal infections are a source of serologically diverse atypical enteropathogenic Escherichia coli and Shiga toxin-producing E. coli strains that commonly possess intimin. Applied and Environmental Microbiology 71 (7): 3405-3412. https://doi.org/10.1128/AEM. 71.7.3405-3412.2005.

Huehn, S., R.M. la Ragione, M. Anjum, M. Saunders, M.J. Woodward, C. Bunge, R, Helmuth, E. Hauser, B. Guerra, J. Beutlich, A. Brisabois, T. Peters, L. Svensson,
G. Madajczak, E. Litrup, A. Imre, S. Herrera-Leon, D. Mevius, D.G. Newell, and B. Malorny. 2010. Virulotyping and antimicrobial resistance typing of Salmonella enterica serovars relevant to human health in Europe. Foodborne Pathogens and Disease 7 (5): 523-535. https://doi.org/10.1089/fpd.2009.0447.

Iweriebor, B.C., C.J. Iwu, L.C. Obi, U.U. Nwodo, and A.I. Okoh. 2015. Multiple antibiotic resistances among Shiga toxin producing Escherichia coli 0157 in feces of dairy cattle farms in Eastern Cape of South Africa. BMC Microbiology 15 (1): 1-9. https://doi.org/10.1186/s12866-015-0553-y.

Jamali, H., K. Krylova, and M. Aïder. 2018. Identification and frequency of the associated genes with virulence and antibiotic resistance of Escherichia coli isolated from cow's milk presenting mastitis pathology. Animal Science Journal 89 (12): 1701-1706. https://doi.org/10.1111/asj.13093.

Karczmarczyk, M., C. Walsh, R. Slowey, N. Leonard, and S. Fanning. 2011. Molecular characterization of multidrug-resistant Escherichia coli isolates from Irish cattle farms. Applied and Environmental Microbiology 77 (20): 7121-7127. https://doi.org/10.1128/AEM.00601-11 [PubMed].

Kumar, A., N. Taneja, S. Singhi, R. Shah, and M. Sharma. 2013. Haemolytic uraemic syndrome in India due to Shiga toxigenic Escherichia coli. Journal of Medical Microbiology 62 (Pt 1): 157-160. https://doi.org/10.1099/jmm.0.044131-0.

Maciel, J.F., L.B. Matter, C. Tasca, D.A.R. Scheid, L.T. Gressler, R.E. Ziech, and A.C.D. Vargas. 2019. Characterization of intestinal Escherichia coli isolated from calves with diarrhea due to Rotavirus and coronavirus. Journal of Medical Microbiology 68 (3): 417-423. https://doi.org/10.1099/jmm.0.000937.

Martínez-Vázquez, A.V., G. Rivera-Sánchez, K. Lira-Méndez, M.Á. Reyes-López, and V. Bocanegra-García. 2018. Prevalence, antimicrobial resistance and virulence genes of Escherichia coli isolated from retail meat in Tamaulipas, Mexico. Journal of Global Antimicrobial Resistance 14: 266-272. https://doi.org/10.101 6/j.jgar.2018.02.016

Mazurek, J., P. Pusz, E. Bok, M. Stosik, and K. Baldy-Chudzik. 2013. The phenotypic and genotypic characteristics of antibiotic resistance in Escherichia coli populations isolated from farm animals with different exposure to antimicrobial agents. Polish Journal of Microbiology 62 (2): 173-179. https:// doi.org/10.2147/OTT.S31260

Mellmann, A., D. Harmsen, C.A. Cummings, E.B. Zentz, S.R. Leopold, A. Rico, K. Prior, R. Szczepanowski, Y.M. Ji, W.L. Zhang, et al. 2011. Prospective genomic characterization of the German enterohemorrhagic Escherichia coli O104: H4 outbreak by rapid next generation sequencing technology. PLoS One 6 (7): e22751. https://doi.org/10.1371/journal.pone.0022751.

Momtaz, H., F.S. Dehkordi, M.J. Hosseini, M. Sarshar, and M. Heidari. 2013b. Serogroups, virulence genes and antibiotic resistance in Shiga toxin-producing Escherichia coli isolated from diarrheic and non-diarrheic pediatric patients in Iran. Gut Pathogens 5 (1): 39. https://doi.org/10.1186/1757-4749-5-39.

Momtaz, H., R. Farzan, E. Rahimi, F. Safarpoor Dehkordi, and N. Souod. 2012. Molecular characterization of Shiga toxin-producing Escherichia coli isolated from ruminant and donkey raw milk samples and traditional dairy products in Iran. The Scientific World Journal 2012: 231342-231313. https:/doi.org/10.1100/2012/231342.

Momtaz, H., F. Safarpoor Dehkordi, E. Rahimi, H. Ezadi, and R. Arab. 2013a. Incidence of Shiga toxin-producing Escherichia coli serogroups in ruminant's meat. Meat Science 95 (2): 381-388. https:/doi.org/10.1016/j.meatsci.2013.04.051.

Navajas-Benito, E.V., C.A. Alonso, S. Sanz, C. Olarte, R. Martínez-Olarte, S. HidalgoSanz, S. Somalo, and C. Torres. 2017. Molecular characterization of antibiotic resistance in Escherichia coli strains from a dairy cattle farm and its surroundings. Journal of the Science of Food and Agriculture 97 (1): 362-365. https://doi.org/10.1002/jsfa.7709.

Ng, L.K., I. Martin, M. Alfa, and M. Mulvey. 2001. Multiplex PCR for the detection of tetracycline resistant genes. Molecular and Cellular Probes 15 (4): 209-215. https://doi.org/10.1006/mcpr.2001.0363.

Nguyen, T.D., T.T. Vo, and H. Vu-Khac. 2011. Virulence factors in Escherichia coli isolated from calves with diarrhea in Vietnam. Journal of Veterinary Science 12 (2): 159-164. https://doi.org/10.4142/jvs.2011.12.2.159.

Olsson, C., T. Olofsson, S. Ahrné, and G. Molin. 2003. The Yersinia HPI is present in Serratia liquefaciens isolated from meat. Letters in Applied Microbiology 37 (4): 275-280. https://doi.org/10.1046/j.1472-765x.2003.01387.x.

Poirel, L., J.Y. Madec, A. Lupo, A.K. Schink, N. Kieffer, P. Nordmann, and S. Schwarz. 2018. Antimicrobial Resistance in Escherichia coli. Microbiology Spectrum 6: 4. https://doi.org/10.1128/microbiolspec ARBA-0026-2017.

Sáenz, Y., L. Briñas, E. Domínguez, J. Ruiz, M. Zarazaga, J. Vila, and C. Torres. 2004. Mechanisms of resistance in multiple-antibiotic-resistant Escherichia coli strains of human, animal, and food origins. Antimicrobial Agents and Chemotherapy 48 (10): 3996-4001. https://doi.org/10.1128/AAC.48.10.3996-4 001.2004. 
Shin, S.W., M.K. Shin, M. Jung, K.M. Belaynehe, and H.S. Yoo. 2015. Prevalence of antimicrobial resistance and transfer of tetracycline resistance genes in Escherichia coli isolates from beef cattle. Applied and Environmental Microbiology 81 (16): 5560-5566. https://doi.org/10.1128/AEM.01511-15.

Sivaraman, G.K., S. Sudha, K.H. Muneeb, B. Shome, M. Holmes, and J. Cole. 2020. Molecular assessment of antimicrobial resistance and virulence in multi drug resistant ESBL-producing Escherichia coli and Klebsiella pneumoniae from food fishes, Assam, India. Microbial Pathogenesis 149: 104581. https://doi.org/10.101 6/j.micpath.2020.104581

WHO., 2017. World Health Organization. Critically important antimicrobials for human medicine: ranking of antimicrobial agents for risk management of antimicrobial resistance due to non-human use.

Wu, R.B., T.W. Alexander, J.Q. Li, K. Munns, R. Sharma, and T.A. McAllister. 2011. Prevalence and diversity of class 1 integrons and resistance genes in antimicrobial-resistant Escherichia coli originating from beef cattle administered subtherapeutic antimicrobials. Journal of Applied Microbiology 111 (2): 511-523. https://doi.org/10.1111/j.1365-2672.2011.05066.x.

Yamamoto, S., M. Nakano, W. Kitagawa, M. Tanaka, T. Sone, K. Hirai, and K. Asano. 2014. Characterization of multi-antibiotic-resistant Escherichia coli Isolated from beef cattle in Japan. Microbes and Environments 29 (2): 136-144. https:// doi.org/10.1264/jsme2.me13173.

Yang, F., S.D. Zhang, X.F. Shang, L. Wang, H.S. Li, and X.R. Wang. 2018 Characteristics of quinolone-resistant Escherichia coli isolated from bovine mastitis in China. Journal of Dairy Science 101 (7): 6244-6252. https://doi. org/10.3168/jds.2017-14156.

Yang, Y., Y.L. Peng, J.Y. Jiang, Z.C. Gong, H. Zhu, K. Wang, Q.N. Zhou, Y. Tian, A.J. Qin, Z.P. Yang, et al. 2021. Isolation and characterization of multidrugresistant Klebsiella pneumoniae from raw cow milk in Jiangsu and Shandong provinces, China. Transboundary and Emerging Diseases 68 (3): 1033-1039. https://doi.org/10.1111/tbed.13787.

\section{Publisher's Note}

Springer Nature remains neutral with regard to jurisdictional claims in published maps and institutional affiliations.

Ready to submit your research? Choose BMC and benefit from:

- fast, convenient online submission

- thorough peer review by experienced researchers in your field

- rapid publication on acceptance

- support for research data, including large and complex data types

- gold Open Access which fosters wider collaboration and increased citations

- maximum visibility for your research: over $100 \mathrm{M}$ website views per year

At $\mathrm{BMC}$, research is always in progress.

Learn more biomedcentral.com/submissions 